\title{
Pengolahan Limbah Cair Tahu Menjadi Nata De Soya Melalui Proses Fermentasi
}

\section{Tofu Liquid Waste Processing Into Nata De Soya Through the Fermentation Process}

\author{
Soerya Dewi Marliyana*, Syahrul Fatrozi, Diana Inas, Fajar Rakhman W, Maulidan Firdaus, \\ Triana Kusumaningsih, Desi Suci Handayani, Venty Suryanti.
}

Program Studi Kimia, Fakultas Matematika dan Pengetahuan Alam, Universitas Sebelas Maret J1. Ir. Sutami 36A Kentingan, Surakarta, Indonesia, 57126

*E-mail: msoerya@staff.uns.ac.id

\begin{abstract}
Abstrak. Pabrik tahu merupakan industri kecil (rumah tangga) yang banyak dikerjakan oleh masyarakat dan pada umumnya jarang memiliki instalasi pengolahan limbah. Adanya keterbatasan dana, pabrik tahu tersebut lebih sering membuang limbahnya langsung ke sungai. Limbah tahu ini akan menimbulkan aroma yang kurang sedap sehingga mengganggu estetika dan kehidupan ekosistem sekitarnya. Salah satu cara untuk mengurangi pencemaran lingkungan, dilakukan pengolahan limbah cair tahu menjadi produk yang lebih bermanfaat yaitu Nata de Soya. Proses pembuatan Nata de Soya melalui fermentasi. Sebanyak satu liter limbah cair tahu diendapkan dan difiltrasi, dilanjutkan dengan pembuatan media tumbuh bakteri Acetobacter xylinum dan difermentasi selama 14 hari. Produk yang terbentuk kemudian dicuci dan direndam selama 3 hari dengan penggantian air rendaman setiap hari. Proses fermetasi limbah cair tahu menghasilkan Nata de soya berbentuk gel, berwarna putih, mempunyai ketebalan $2 \mathrm{~mm}$, kadar air $79,31 \%$ dan densitas sebesar 0,85 . Pengolahan dalam penelitian ini yang terbukti berhasil mengubah limbah cair tahu menjadi Nata de Soya merupakan salah satu cara mengurangi pencemaran lingkungan dan dapat meningkatkan nilai ekonomi.
\end{abstract}

Kata kunci: fermentasi, limbah cair tahu, Nata de soya

Abstract. Tofu factories are small (household) industries that are mostly done by the community and generally rarely have sewage treatment plants. Due to limited funds, these tofu factories often dispose of their waste directly into the river. This tofu waste will cause an unpleasant aroma that will disturb the aesthetics and life of the surrounding ecosystem. One of the ways to reduce environmental pollution is to process tofu liquid waste into a more useful product, namely Nata de Soya. The process of making Nata de Soya can be done through fermentation. As much as one liter of tofu liquid waste was deposited and filtered following by making a growing medium for Acetobacter xylinum bacteria and was then fermented for 14 days. The product was then washed and soaked for 3 days with daily replacement of water immersion. The fermentation process of tofu wastewater produced Nata de soya as a white gel and having a thickness of $2 \mathrm{~mm}$, a water content of $79.31 \%$, and a density of 0.85 . The treatment presented in this paper which successfully converted tofu wastewater into Nata de Soya is one way to reduce environmental pollution and to increase the economic value.

Keywood: tofu liquid waste, fermentation, Nata de soya 


\section{Pendahuluan}

Industri tahu merupakan industri kecil yang banyak tersebar di Indonesia. Lokasi industri tahu kebanyakan menyatu dengan pemukiman penduduk, sehingga muncul permasalahan dengan lingkungan sekitar. Industri tahu menghasilkan limbah cair yang dapat mengakibatkan pencemaran terhadap lingkungan. Industri tahu pada umumnya memproduksi mulai dari $1.200 \mathrm{~kg}-1.500 .000 \mathrm{~kg}$ tahu per tahun dengan jumlah limbah cair yang dihasilkan mencapai $2 \mathrm{~m}^{3}$ untuk setiap pengolahan 1 kuintal kedelai [1].

Limbah cair tahu merupakan limbah yang paling dominan dihasilkan dalam proses pembuatan tahu karena dalam proses pembuatan tahu membutuhkan banyak air untuk memperoleh produk utama yang diinginkan. Limbah cair tahu memiliki kandungan air 90,74\%, protein 1,8\%, lemak 1,2\%, serat kasar 7,36\% dan abu $0,32 \%$ [2]. Selain itu, limbah cair tahu mengandung zat organik yang dapat menyebabkan pesatnya pertumbuhan mikroba dalam air sehingga mengakibatkan kadar oksigen dalam air menurun. Permasalah lain yang timbul oleh adanya limbah cair tahu adalah bau busuk dan $\mathrm{pH}$ rendah yang didapat karena dalam proses pembuatan tahu menggunakan asam cuka. Hal tersebut dapat mengakibatkan terjadinya pencemaran lingkungan, baik perairan, udara, maupun tanah, serta dapat menimbulkan berbagai masalah sanitasi dan kesehatan masyarakat [3]. Limbah tahu yang dibuang langsung ke badan air misalnya sungai tanpa mengalami pengolahan terlebih dahulu dapat mengakibatkan turunnya kualitas perairan [4] dan berubahnya tatanan ekosistem perairan yang disebabkan oleh matinya organisme akuatik [5]. Oleh karena itu, diperlukan teknologi pengolahan limbah tahu agar mampu mengurangi pencemaran dan permasalahan lingkungan tersebut. Berdasarkan uraian tersebut, artikel ini melaporkan pengolahan limbah cair tahu menjadi Nata de Soya dengan metode fermentasi sebagai upaya mengurangi dampak negatif limbah cair tahu dan memanfaatkanya sebagai sumber bahan baku penghasil produk pangan bergizi dan bernilai ekonomis.

\section{Metode}

Alat yang digunakan neraca, wadah pemeram, panci, aluminium foil, kasa, saringan, gelas ukur dan hot plate. Bahan-bahan yang digunakan limbah cair tahu, glukosa, ZA foodgrade, asam asetat dan Acetobacter xylinum (bakteri fermentasi).

\subsection{Pembuatan Nata de soya}

Limbah tahu segar sebanyak 1 L diendapkan, disaring dengan kain kassa, dipanaskan sampai mendidih sambil diaduk-aduk. Kemudian ditambahkan $10 \mathrm{~mL}$ asam asetat dan $80 \mathrm{~g}$ gula pasir diaduk hingga gula larut. Setelah larut semua ditambahkan ZA foodgrade $5 \mathrm{~g}$. Media nata ditambahkan bibit/starter nata (1 liter media nata membutuhkan $50-100 \mathrm{~mL}$ bibit). Kemudian pindahkan ke dalam wadah-wadah fermentasi dengan ketinggian media $4 \mathrm{~cm}$. wadah ditutup dengan aluminium foil. Wadah berisi media disimpan diruang fermentasi selama 12 - 15 hari sampai terbentuk lapisan nata. Setelah terbentuk lapisan, lapisan tersebut di tiriskan. Kemudian lapisan tersebut dicuci dengan air bersih untuk menghilangkan ureanya dan direndam selama 3 hari dengan diganti air rendamannya setiap hari.

\subsection{Uji kadar air}

Cawan porselin dipanaskan dalam oven dengan suhu $100{ }^{\circ} \mathrm{C}$ selama 15 menit kemudian dinginkan dan catat bobot kosongnya $\left(\mathrm{W}_{\mathrm{O}}\right)$. Dilakukan penimbangan sampel nata sebanyak $3-5 \mathrm{~g}$ dalam cawan porselin yang telah diketahui bobot kosongnya $\left(\mathrm{W}_{\mathrm{S}}\right)$. Selanjutnya dipanaskan dalam oven bersuhu $105{ }^{\circ} \mathrm{C}$ selama satu jam. Cawan berisi nata setelah dipanaskan kemudian didinginkan dalam eksikator. Cawan berisi residu ditimbang sampai bobot tetap $\left(\mathrm{W}_{\mathrm{R}}\right)$. Kemudian dihitung kadar air dalam contoh dengan menggunakan rumus sebagai berikut.

$$
\text { Kandungan air }(\%)=\frac{\left(W_{R}-W_{o}\right)}{\left(W_{S}-W_{o}\right)} \times 100 \%
$$




\subsection{Penentuan densitas dan kuat tarik}

Air dimasukkan kedalam gelas ukur dan catat volumenya sebagai (V1). Sampel Nata ditimbang dan dicatat massanya. Selanjutnya sampel nata yang telah ditimbang dimasukkan kedalam gelas ukur yang berisikan air dan dicatat perubahan volumenya sebagai (V2) dan dihitung volume nata (V2 - V1). Pengukuran densitas menggunakan persamaan sebagai berikut:

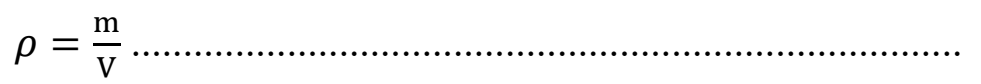

Pengukuran kuat tarik dilakukan dengan alat penentuan kuat tarik yang dilakukan di laboratorium MIPA Terpadu UNS.

\section{Hasil dan Pembahasan}

Pengolahan limbah cair tahu menjadi Nata de soya dengan proses fermentasi selama 14 hari telah menghasilakan Nata de soya berbentuk gel, berwarna putih, mempunyai ketebalan $2-5 \mathrm{~mm}$. Perlakuan proses fermentasi selama 14 hari adalah waktu yang optimal untuk terbentuknya Nata de soya. Salah satu faktor yang dapat mempengaruhi karakteristik nata adalah lama fermentasi. Selama fermentasi bakteri Acetobacter xylinum dapat mengubah 19\% gula menjadi selulosa. Selulosa yang terbentuk akan membentuk benang yang bersama-sama polisakarida membentuk jalinan yang terus menerus menebal menjadi lapisan nata [6]. Lapisan nata akan terbentuk secara optimum bila waktu fermentasi cukup. Waktu fermentasi yang terlalu cepat mengakibatkan tekstur nata menjadi lembek dan lapisan nata yang terbentuk tipis sehingga serat yang dihasilkan juga sedikit. Waktu fermentasi yang terlalu lama menyebabkan aroma nata sangat asam, lapisan nata tebal dan tekstur menjadi keras [7].

Berdasarkan penelitian Azhari (2015), ketebalan Nata de soya yang terbentuk sangat dipengaruhi oleh kandungan protein yang terdapat pada limbah cair tahu dan bakteri Acetobacter xylinum yang ditambahkan. Jumlah starter bakteri yang diberikan sangat berpengaruh terhadap ketebalan Nata de Soya yang dihasilkan. Jumlah starter bakteri yang diberikan harus sebanding dengan jumlah ketersediaan nutrisi pada media fermentasi, jika tidak seimbang akan mengganggu proses pembentukan selulosa serta terjadi proses kanibal (saling memakan bakteri) [8]. Starter bakteri Acetobacter xylinum merupakan bakteri yang menghasilkan serat-serat selulosa yang sangat halus. Serat-serat ini dapat membentuk suatu jaringan pada lapisan permukaan antara udara dan cairan yang disebut pelikel. Pelikel memiliki ketebalan kira-kira $10 \mathrm{~mm}$ bergantung pada masa pertumbuhan mikroba atau starter bakteri yang digunakan. Pelikel-pelikel terdiri atas pita-pita yang mengandung kristalin yang tinggi [9].

Pengukuran kadar air dari Nata de soya yang dihasilkan diperoleh nilai sebesar $79,31 \%$. Hasil pengukuran densitas diperoleh nilai sebesar 0,85 sedangkan uji kuat tarik ditampilkan dalam Gambar 1 .

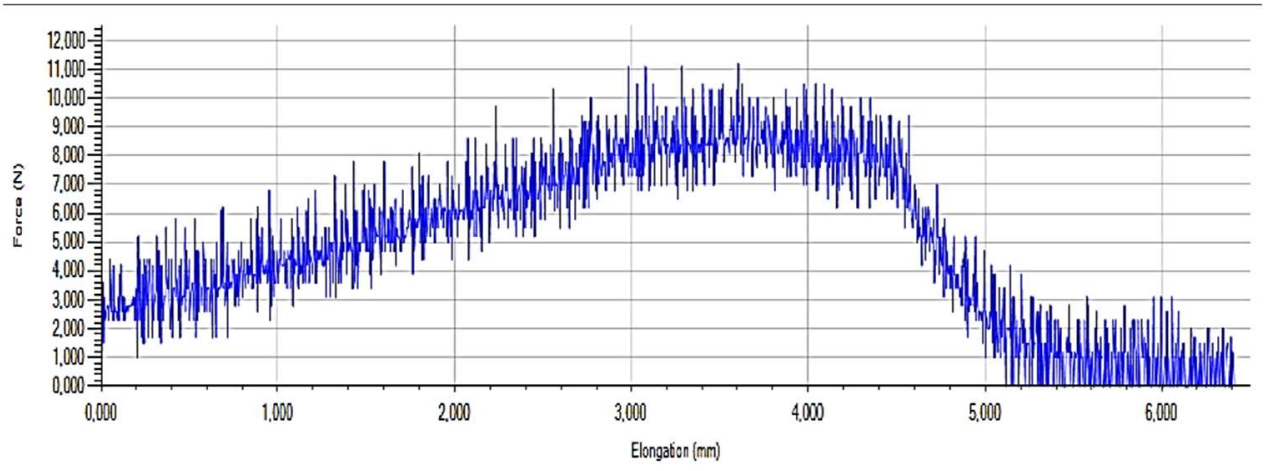


Gambar 1. Grafik kuat tarik Nata de soya limbah cair tahu

Uji juat tarik yang ditampilkan dalam Gambar 1 menunjukkan nilai sebesar 27,58 N/mm². Hasil pengukuran densitas dan kuat tarik terhadap Nata de soya menunjukkan Nata de soya yang diperoleh mempunyai kandungan serat yang tinggi. Hasil tersebut menunjukkan Nata de soya yang berasal dari pengolahan limbah cair tahu masih dapat dikonsumsi.

\section{Kesimpulan}

Pengolahan limbah cair tahu melalui proses fermentasi, menghasilkan produk Nata de soya dengan bentuk gel, berwarna putih dan kandungan serat cukup tinggi. Pengolahan limbah cair tahu menjadi produk makanan terutama Nata de soya sangat besar dan dapat meningkatkat nilai ekonomi bagi masyarakat.

\section{Referensi}

[1] Herlambang, A., 2002, Teknologi Pengolahan Limbah Cair Industri Tahu. Pusat Pengkajian dan Penerapan Teknologi Lingkungan (BPPT) dan Badan Pengendalian Dampak Lingkungan Samarinda.

[2] Trismilah, 2001, Pemanfaatan Limbah Cair Tahu Sebagai Medium Dan Pengaruhnya Terhadap Pertumbuhan Bakteri Penghasil Enzim Protease. Proseding Seminar Keanekaragaman Hayati Dan Aplikasi Biotekologi Pertanian. Jakarta: BPPT.

[3] Subekti, S., 2011, Pengolahan limbah cair tahu menjadi biogas sebagai bahan bakar alternatif. Prosiding SNST Fakultas Teknik, 1(1).

[4] Sujaul, I.M., Hossain, M.A., Nasly, M.A. and Sobahan, M.A., 2013, Effect of industrial pollution on the spatial variation of surface water quality. American Journal of Environmental Sciences, 9(2), p. 120 .

[5] Azhari, A., Sunarto, S. and Wiryanto, W., 2015, Pemanfaatan Limbah Cair Tahu Menjadi Nata de Soya dengan Menggunakan Air Rebusan Kecambah Kacang Tanah dan Bakteri Acetobacter xylinum. Ekosains, 7(1).

[6] Misgiyarta, 2006, Fermentasi Nata Dengan Substrat Limbah Buah Nanas dan Air Kelapa. Bogor : Balai Besar Penelitian dan Pengembangan Pascapanen Pertanian.

[7] Budiarti, R.S., 2008, Pengaruh Konsentrasi Starter Acetobacter xylinum terhadap Ketebalan dan Rendemen Selulosa Nata De Soya. Biospecies, 1(1).

[8] Puji, L. Nitariani, E. Ani, S. and Yadi, S., 2014, Study on the Production of Bacterial Cellulosa from Acetobacter xylinum using Agro-Waste. Jordan Journal of Biological Sciences. ISSN1995-6673. 7(1), 75- 80.

[9] Khairul, A., 2010, Produksi Nata de Coco. Bogor: ITB 